people of different ethnic backgrounds, language preferences, and political orientations. One of the chapters, for example, features Natan Khazin (https://ukrainianjewishencounter.org/en/religious-jew-aids-ukrainian-army/), an émigré from Odessa who served in the Israel Defense Forces and became a "commander of operations" on Kyiv's Maidan (51-52). Concurrently, Shore acknowledges palpable tensions between right-wing groups and leftist activists inside the encampment (54-55). She also mentions a gender-based division of labor: "men were building barricades, women were making Molotov cocktails" (111). Beyond making Molotov cocktails and slicing sandwiches, the interviewed women performed such critical tasks as the coordination of transportation from L'viv to Kyiv (43), and the management of a hotline for protesters (45). In a remarkable feat of solidarity, a diverse body of protesters pulled their efforts together to sustain "a parallel polis" on the Maidan (44).

The book is written in Hemingway-esque style, making judicious choice of vignettes and swiftly moving from one topic to another. However, the book lacks such common features of a scholarly publication as footnotes and an index. The citation of several academic sources would have been especially helpful to the reader when the book touches upon some controversy-ridden issues in Ukrainian historiography.

Taken as a whole, The Ukrainian Night contributes to the bourgeoning literature on Ukraine's Revolution of Dignity by capturing the essence of the revolution through the lens of Ukrainian intellectuals. The book will be of interest to students of east European history, political sociology, and comparative politics. Moreover, the book is well positioned to reach a wide audience outside academia.

OLENA NiKOLAYENKO Fordham University

\title{
Lost in the Shadow of the Word: Space, Time, and Freedom in Interwar Eastern
} Europe. By Benjamin Paloff. Evanston: Northwestern University Press, 2016. xii, 359 pp. Appendix. Notes. Bibliography. Index. Photographs. \$99.95, hard bound, $\$ 39.95$, paper.

doi: $10.1017 /$ slr.2018.321

The title of Benjamin Paloff's book, Lost in the Shadow of the Word, can be read as a playful response to Milan Kundera's definition of central European literature as a European "laboratory of the twilight." In his book, Paloff puts the troublesome idea of central Europe behind, and-without Joseph Brodsky's radicalism in this matter-discusses an eastern Europe that includes Russia. This opening gesture allows for the question of one of the most significant-as well as problematic-conceptual operations of the book: the cultural decentralization of east European modernism; that is, removing into a shadow its centers: Vienna, Paris, and Berlin (along with the Russian detour). Here, one may ask what Andrei Platonov, a Russian proletarian writer, has in common with Bruno Schulz, a Polish-Jewish writer from Galicia. Paloff also brings in other writers in pairs and a trio: Czesław Miłosz and Osip Mandel'shtam, Nikolai Zabolotskii and Vítězslav Nezval, and Witold Gombrowicz, Karel Čapek, and Richard Weiner. For Paloff, however, the intuitively unbridgeable differences within the clusters he constructs pose a challenge for establishing more esoteric, conceptual affinities. So, what is the concept that keeps these authors together?

"This book is about in-betweeness" (3), Paloff proclaims in the first sentence. He then explicates: it is "about being suspended in the kind of in-betweeness 
that is engendered by indeterminacy in space and time"; it "argues that the new understanding of space and time that emerged at the turn of the [twentieth] century fundamentally changed the representation of individual subjectivity in East European literature" (3). Further, the author declares that a "more ambitious way of describing [his] book" (3) is "that it provides a contemporary diagnosis of what we mean when we characterize Eastern European Modernism as uncanny, strange, or simply 'Kafkaesque"' (3). If resisting the temptation to ask scholastic questions about the ontological (and temporal) status of the ladder populated by the two-way traffic of confused angels from Jacob's dream-so important to many east European artists-or, Nikolai Stavrogin's anthropology, based on the concept of "transitoriness," we could translate this theoretical claim into a more lapidary statement: this is a book about literary responses to modernity in eastern Europe in the 1920s and 1930s. In the conclusion of his "theoretical" first chapter, drawing from his analyses of Georg Lukács's and Mikhail Bakhtin's early works, Paloff introduces the ethical dimension to his all-embracing concept, describing the position of the east European subject as being unbound in space and time, whereby one is never entirely independent of, or fully absorbed into, the collective." Without "boundaries and definitions there is no possibility of escape" (35), Paloff gloomily concludes. Thus, the construction he builds in the opening chapter could provide us with a useful conceptual paraphrase of modernist aesthetics; however, for instance, his reading of Theory of the Novel seems to be problematic: one has the impression that in his analysis, he takes Lukács's expressionistic metaphors at face value, skating along surfaces, and, perhaps, trusting too much in the interpretations offered by the essays of Milan Kundera.

It is hard to resist the thought that in the context of literature, these theoretical reflections lead not only to Albert Einstein, Emmanuel Levinas, Martin Heidegger, Jean-Luc Nancy, or, "à la Adorno" (87) and Giorgio Agamben, the theorists of "inbetweenness" nominated by Paloff, but also, if not first of all to the textbook, permit me the word, "origin," that is, to the uninvited guests, Gustave Flaubert and Charles Baudelaire. Defining the phenomenology of modernity and the newness of the present ("in-betweeness," or, vertical and horizontal "chronotopes," intermingled with each other in Paloff's Bakhtinian language) in the essay "The Painter of Modern Life," Baudelaire sees it as "ephemeral, the fugitive, the contingent, the half-art whose other half is the eternal and the immutable," thus, in a word, as the present book teaches us, "Kafkaesque."

Undoubtedly, Paloff's book is an important contribution to comparative east European modernism, if not the first, considering its scale. Its close-reading exercises of works of poetry and prose written in three different languages is yet another strength of this book; let us not forget that the author is not only a scholar but also a successful translator of Czech and Polish literature. But, perhaps, we should be more skeptical about Paloff's encouragement to read through "the paradigm of intermediacy" as he inflates his concept in the conclusion with another nineteen authors (including Albert Camus, Jean-Paul Sartre, Boris Pilniak, and Paul Auster), listed in the penultimate paragraph of the book. Moreover, there is no need to "reevaluate the spatial-temporal construct of Proust, Mann, and Joyce" (251), as the unstoppable author armed with his "paradigm" postulates. This is, of course, simply because similar work has been done so many times in the past, and definitely by the year 1960, when Professor Harry Levin published his essay, "What was Modernism?” 